\title{
The Effect of Teaching Style Variations on Student's Learning Achievement at Sasmita Jaya Vocational School, South Tangerang
}

\author{
Dewi Sartika; Sam Cay; Ali Zaenal Abidin \\ Universitas Pamulang, Email : dosen02208@unpam.ac.id; dosen02207@unpam.ac.id \\ alizaenalabidin@unpam.ac.id
}

\section{ARTICLES \\ INFORMATION}

ABSTRACT

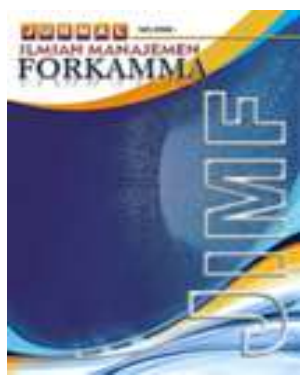

JURNAL ILMIAH MANAJEMEN FORKAMMA

Vol.4, No.3, Juli 2021

Halaman : 229-236

(C) LPPM \& FORKAMMA

Prodi Magister Manajemen UNVERSITAS PAMULANG

ISSN (online) : 2599-171X

ISSN (print) : :2598-9545

Keyword :

Teaching Style; Student Achievement

JEL. classification :

O15,

Contact Author :

PRODI

MAGISTER MANAJEMEN \& FORKAMMA UNPAM

JL.Surya Kencana No.1 Pamulang

Tangerang Selatan - Banten

Telp. (021) 7412566, Fax (021) 7412491

Email : jurnalforkamma.unpam@gmail.com
Abstract. The goal to be achieved in this study is to determine the effect of teacher teaching style on student achievement at SMK Sasmita Jaya, South Tangerang. The time of the research takes place from December 2020 to April 2021. In improving education, of course, it is influenced by teaching and learning interactions during the learning process. The intended interaction is a reciprocal relationship between teachers and students on the teaching and learning process. This research method is an associative research conducted by quantitative approach. The respondents of this study were 75 students of XI Marketing class at SMK Sasmita Jaya, South Tangerang. And the sample used was 75 respondents using the saturated sample technique. Collecting data using interviews, questionnaires, documentation, and literature study. While the data analysis using Validity Test, Reliability Test, Simple Linear Regression, Correlation Coefficient, Coefficient of Determination and Significance Test. The results in this study indicate that the value of $Y=16.948+0.550 x$. The results of the calculation of the correlation coefficient indicate that there are not examined in this study. The results of the significant test calculation, it is known (4.282 > 1.993) then HO is rejected and $\mathrm{H} 1$ is accepted, thus it is evident that there is a significant influence between teacher teaching styles on student achievement at SMK Sasmita Jaya, South Tangerang. 


\section{A. INTRODUCTION}

Education has a big role in the progress of the nation. The success of a nation can be achieved if the education system in it can take place well and keep up with the times. Education is not only about science (SCIENCE), education is closely related to everyday life. Both in the fields of economy, politics and culture. It can be proven that after receiving education, a person becomes a human being with noble character, morality and good ethics. In improving education, of course, it is influenced by teaching and learning interactions during the learning process. The intended interaction is a reciprocal relationship between teachers and students in the teaching and learning process. In every teaching and learning process, it is hoped that this does not happen

in a passive situation where there is no communication or other social interaction between teachers and students. Interaction in the teaching and learning process is needed in order to create an effective and conducive learning atmosphere. A pleasant and comfortable classroom atmosphere for students certainly affects the attention of students to participate in the learning process to the fullest. Interaction here is expected to be mutually sustainable between teachers and students, this is to avoid the occurrence of mutual surup communication which then does not lead to the expected interaction goals.

Teaching and learning activities are largely determined by the cooperation between teachers and students. Teachers are required to be able to present material optimally so that new creativity and ideas are needed to develop ways of presenting subject matter in schools, this is reflected in the teacher's teaching attitude in the classroom. The teacher is the party closest to the students in the implementation of daily education, and the teacher is the parties who have the biggest role in determining the success of students in achieving educational goals.

Vocational High School (SMK) as a form of vocational education unit which is education that prepares students to work in certain fields. In particular, SMK aims to prepare students to be able to work either independently or to fill job vacancies in the business and industrial world. As a middle-class workforce in accordance with the fields and expertise programs of interest, equip students to be able to have a career, be tenacious and persistent in competing and be able to develop a professional attitude in the field of interest. Not only that, students are equipped with science and technology to be able to develop themselves through higher education levels.

\section{B. LITERATURE REVIEW}

According to Mukhtar (2015) "states that the notion of psychological learning is a process of change, namely changes in behavior as a result of interaction with the environment in meeting the needs of life". The teaching style of teachers according to Conti in Ahmed (2013) "is divided into 2 types, namely teaching styles with teacher centered and student centered approaches. Both approaches have their respective advantages and disadvantages when applied in the learning process". The teaching style approach used by the teacher will be effective if it is in line with the objectives, subject matter, and interests and needs of students, both in the form of group and individual teaching. The main obligation of a student, of course, is to learn. According to Hamalik (2016) learning is the modification or strengthening of behavior through experience (learning is defined as the modification or strengthening of behavior through experiencing).

According to Zainal Aqib (2013), "variations in teaching styles are changes that occur in teaching and learning activities to increase enthusiasm, reduce boredom and boredom experienced by students".

According to Zainal Asri (2013) "the skill of holding variations (variation stimulus) is a teacher activity in the context of the learning interaction process aimed at overcoming the 
boredom of participants. students, so that in the process of learning situations always show perseverance and full participation".

According to Bisri Mustofa (2015) "learning is a process activity and is a very fundamental element in the implementation of every type and level of education. This means that the success or failure of achieving educational goals is very dependent on the learning process experienced by students, both when they are in school". as well as the home environment or his own family Another opinion that: "learning achievement as a form of assessment of the results of knowledge transfer activities (learning) carried out in schools and represented in the form of numbers as a form of standard assessment of the achievement of a student within a span of time. pre-determined." Dislen (2013).

\section{RESEARCH METHODOLOGY}

This research was conducted at SMK Sasmita Jaya Jl. Surya Kencana No.2 Pamulang, South Tangerang 15417. The implementation of this research was carried out in December 2020 - April 2021. In this study, the authors used quantitative research and a descriptive approach. According to Sugiyono (2017) "population is a generalization area consisting of objects or subjects that have certain qualities and characteristics set by researchers to be studied and then drawn conclusions". Based on the research location that has been determined, the population that is used as the object of this research is the students of SMK Sasmita Jaya class XI majoring in Marketing as many as 75 people. According to Sugiyono (2017) "the sample is part of the number and characteristics possessed by the population. If the population is large and the research is not possible to study everything in the population, for example due to limited funds, manpower and time, the research can use samples taken from that population". In this study, the authors used saturated sampling. Saturated sampling is a sampling technique when all members of the population are used as samples. Sugiyono (2017:85). This is often done when the population is relatively small, or the study wants to make generalizations with very small errors. So in this study, the writing took a sample of 75 people.

\section{RESULTS AND DISCUSSION}

1. Validity Test

Summary of Instrument Validity Variable Teacher Teaching Style (X)
\begin{tabular}{|c|c|c|c|}
\hline \multirow{2}{*}{ Statement } & \multicolumn{3}{|c|}{ Teacher's Teaching Style } \\
\cline { 2 - 4 } & $\begin{array}{c}\mathbf{r} \\
\text { count }\end{array}$ & $\begin{array}{c}\mathbf{r} \\
\text { table }\end{array}$ & Information \\
\hline 1 & 0,649 & 0,227 & Valid \\
\hline 2 & 0,451 & 0,227 & Valid \\
\hline 3 & 0,557 & 0,227 & Valid \\
\hline 4 & 0,629 & 0,227 & Valid \\
\hline 5 & 0,653 & 0,227 & Valid \\
\hline 6 & 0,654 & 0,227 & Valid \\
\hline 7 & 0,322 & 0,227 & Valid \\
\hline 8 & 0,261 & 0,227 & Valid \\
\hline 9 & 0,553 & 0,227 & Valid \\
\hline 10 & 0,596 & 0,227 & Valid \\
\hline
\end{tabular}

Summary of Instrument Validity Student Achievement Variable (Y) 
ISSN (print) : 2598-9545 \& ISSN (online) : 2599-171X

\begin{tabular}{|c|c|c|c|}
\hline \multirow{2}{*}{ Statement } & \multicolumn{3}{|c|}{ Student achievement } \\
\cline { 2 - 4 } & $\begin{array}{c}\mathbf{r} \\
\text { count }\end{array}$ & $\begin{array}{c}\mathbf{r} \\
\text { table }\end{array}$ & Information \\
\hline 1 & 0,554 & 0,227 & Valid \\
\hline 2 & 0,542 & 0,227 & Valid \\
\hline 3 & 0,384 & 0,227 & Valid \\
\hline 4 & 0,692 & 0,227 & Valid \\
\hline 5 & 0,592 & 0,227 & Valid \\
\hline 6 & 0,719 & 0,227 & Valid \\
\hline 7 & 0,631 & 0,227 & Valid \\
\hline 8 & 0,698 & 0,227 & Valid \\
\hline 9 & 0,655 & 0,227 & Valid \\
\hline 10 & 0,526 & 0,227 & Valid \\
\hline
\end{tabular}

2. Reliability Test

Value of Variable Item Variable Teacher Teaching Style (X)

\begin{tabular}{|c|c|}
\hline \multicolumn{2}{|c|}{$\begin{array}{c}\text { Variable Reliability Test } \\
\text { Calculation (X) Teaching Style } \\
\text { Teacher }\end{array}$} \\
\hline 1 & 0,397 \\
\hline 2 & 0,631 \\
\hline 3 & 0,682 \\
\hline 4 & 0,649 \\
\hline 5 & 0,474 \\
\hline 6 & 0,319 \\
\hline 7 & 0,319 \\
\hline 8 & 0,548 \\
\hline 9 & 0,609 \\
\hline 10 & 0,595 \\
\hline$\sum$ & $\mathbf{5 , 2 2 3}$ \\
\hline
\end{tabular}




\section{Value of Variable Item Variable Student acievemet (Y)}

\begin{tabular}{|c|c|}
\hline \multicolumn{2}{|c|}{$\begin{array}{c}\text { Variable Reliability Test } \\
\text { Calculation (Y) Student } \\
\text { Acievement }\end{array}$} \\
\hline 1 & 0,817 \\
\hline 2 & 0,613 \\
\hline 3 & 0,463 \\
\hline 4 & 0,680 \\
\hline 5 & 0,476 \\
\hline 6 & 0,809 \\
\hline 7 & 0,427 \\
\hline 8 & 0,707 \\
\hline 9 & 0,600 \\
\hline 10 & 0,454 \\
\hline$\sum$ & $\mathbf{6 , 0 4 6}$ \\
\hline
\end{tabular}

\section{Simlpe Liniar Regression}

$$
Y=16,948+0,550
$$

Based on the results of the above calculations can be explained as follows:

1. The value of the intercept constant is 16.948 , which is the constant value (a). Stating that if $X=0$, then the value of $Y=16,948$.

2. The regression coefficient value of the Teacher Teaching Style variable $(X)$ on the Student Learning Achievement variable $(Y)$ is 0.550 . This means that if the Teacher's Teaching Style $(X)$ is reduced by 1 unit, it will increase student

3. learning achievement by 0.550 .

\section{Correlation coefficient}

Based on the results of the above analysis using Product Moment Correlation, an rxy value of 0.448 is obtained, which means that there is a fairly strong positive relationship between Teacher Teaching Style and Student Achievement at SMK Sasmita Jaya.

\section{Coefficient of Determination}

$$
\begin{aligned}
\mathrm{KD} & =r^{2} \times 100 \% \\
& =0,448^{2} \times 100 \% \\
& =0,201 \times 100 \% \\
& =20,07 \%
\end{aligned}
$$

The value of the coefficient of determination $K D=20.07 \%$ This shows that the contribution of the Teacher Teaching Style variable $(X)$ has an effect on the Student Learning Achievement variable (Y) of $20.07 \%$, while the rest is $00 \%-20.07 \%)=79.93 \%$ is influenced by other factors. Such as work discipline, leadership style, work performance, motivation and others. 


\section{Significant test}

$$
\begin{aligned}
& t=\frac{0,448 \cdot \sqrt{ } 73}{\sqrt{ } 0,799} \\
& t=\frac{0,448 \cdot 8,544}{\frac{0,8938}{3,828}} \\
& t=\frac{0,894}{t}=4,282
\end{aligned}
$$

Thus, because tcount is greater than ttable, $(4,282>1,993)$, it shows that there is a significant effect, then $\mathrm{Ho}$ is rejected or $\mathrm{Ha}$ is accepted. This means that the variable of Teacher Teaching Style (X) has a significant influence on Student Achievement $(\mathrm{Y})$ at SMK Sasmita Jaya.

\section{E. CONCLUSION}

Teaching Style Teachers at SMK Sasmita Jaya got a pretty good response, the authors conclude based on the answers of all 75 respondents with 10 statements, $39.20 \%$ "Strongly Agree" $+50.53 \%$ "Agree" $=89.73 \%$. From the data above, the highest answers of "Strongly Agree" and "Agree" are found in the Personalized Teaching Style indicator.

Student Achievement at SMK Sasmita Jaya got a pretty good response, the authors conclude based on the answers of all 75 respondents with 10 statements as much as $27.73 \%$ answered "Strongly Agree" $+54.13 \%$ "Agree" $=81.86 \%$. From the data above, the highest answers of "Strongly Agree" and "Agree" are found in the Study Habits indicator.

From the regression equation $Y=a+b X$, it is known that $Y=16.948+0.550 X$, which means that if the value of the Teacher's Teaching Style increases by 1 , the value of Student Learning Achievement will increase by 0.550 . There is a fairly strong influence between Teacher Teaching Styles on Student Achievement at SMK Sasmita Jaya, namely from the results of correlation analysis (rxy) the correlation between Teacher Teaching Styles and Student Learning Achievements is 0.448 . This shows that there is a fairly strong relationship between Teacher Teaching Style and Student Learning Achievement because it is in the range $0.40-0.599$, meaning that the better the Teacher's Teaching Style, the higher the Student Learning Achievement. The coefficient of determination of the variable (X) Teacher Teaching Style on the variable $(Y)$ Student Achievement is $20.07 \%$ and the remaining $79.93 \%$ variable (Y) Student Learning Achievement is influenced by other factors that the authors did not include in this study. Based on the results of testing the hypothesis test formula, tcount $>$ ttable is $4,282>1,993$, which means that $\mathrm{Ho}$ is rejected and $\mathrm{Ha}$ is accepted, so Teacher Teaching Style has a significant influence on Student Achievement at SMK Sasmita Jaya.

Along with advances in technology and the level of rapid development of education, educational institutions must focus more attention on the level of Student Achievement for all students in realizing educational goals and objectives so as not to deviate from what was previously planned. Furthermore, suggestions will be submitted as input for the school in determining the right Teacher Teaching Style, the suggestions are:

1. In the future, it is suggested for teachers to pay more attention to the teaching style given by the teacher. This is based on the results of the author's analysis which states that the Teacher's Teaching Style has a significant influence towards improving student learning achievement, especially in providing opportunities for students to learn with other media and actively discuss in class.

2. Educational institutions should maintain to always evaluate and adjust the Teaching Style of Teachers in a certain period by: 
a. Teaching Style Teachers must always be adapted to the needs of students because then it will automatically improve the learning achievement of the students concerned.

b. Pay attention to how to deliver material that pleases students so that it can increase enthusiasm for learning.

c. Schools should be able to provide fun learning facilities in addition to textbooks so that students can optimally absorb the material provided by the teachers.

\section{REFERENCE}

Ahmed, Ahmed Khaled. 2013. Teacher Centered Versus Learned Centered Teaching Style. The Journal of Global Business Management.

Aqib, Zainal. 2013. Model-model Media dan Strategi Pembelajaran Kontekstual (Inovatif).Bandung: Yrama Widya

Arwafe. (2015). Fungsi prestasi belajar. Dalam https://arwave.blogspot.co.id/2015/10/fungsi-prestasi-belajar.html. Diakses pada tanggal 29 Mei 2018

Asril, Zainal. 2013. Micro Teaching. Jakarta: PT Rajagrafindo Persada.

Dislen, G. 2013. The Reasons of Lack of Motivation from the Students and Teachers Voices. The Journal of Academic Social Science, 1(1), 2013.

Djamarah, Syaiful Bahri dan Aswan Zain. 2013. Strategi Belajar Mengajar.Jakarta: Rineka Cipta.

Fathurohman, Muhammad dan Sulistyorini. 2012. Belajar dan Pembelajaran, Yogyakarta: Teras hal.213

Hamalik, Oemar. 2016. Proses Belajar Mengajar. Jakarta: PT. Bumi Aksara.

Kurniawan, Aris. 2015. Pengertian prestasi menurut para ahli beserta macamnya. Dalam www.gurupendidikan.co.id/pengertian-prestasi-menurut-para-ahlibesertamacamnya/. Diakses pada tanggal 29 Mei 2019

Lesmana, R., Sunardi, N., \& Kartono. The Effect of Financing and Online Marketing on MSMEs Income Increasing at Intermoda Modern Market BSD City Tangerang Selatan. American Journal of Humanities and Social Sciences Research (AJHSSR), 5(7), 25-34

Lesmana, R., Sunardi, N., Hastono, H., \& Widodo, A. S. (2021). Perceived Quality Membentuk Customer Loyalty via Brand Equity pada Pengguna Smartphone Merek Xiaomi di Tangerang Selatan. Jurnal Pemasaran Kompetitif, 4(2), 157167

Lesmana, R., Sutarman, A., \& Sunardi, N. Building A Customer Loyalty Through Service Quality Mediated by Customer Satisfaction. American Journal of Humanities and Social Sciences Research (AJHSSR), 5(3), 38-45

Mangkunegara, A.A Anwar Prabu. 2013. "Manajemen Sumber Daya Manusia”. Bandung: PT. Remaja Rosdakarya

Muchtar, Al. 2015. Dasar Penelitian Kualitatif. Bandung: Gelar Pustaka Mandiri

Mustofa, Bisri. 2015. Psikologi Pendidikan, Yogyakarta:Parama IImu, Hal.127

Ramayulis. 2015. filsafat pendidikan islam. RaJakarta: kalam mulia hal .346-362 
Rohwati, M. 2012. Penggunaan education game untuk meningkatkan hasil belajarIPA biologi konsep klasifikasi makhluk hidup. Jurnal Pendidikan IPA Indonesia, 1(1).

Rudy, R., Sunardi, N., \& Kartono, K. (2020). Pengetahuan Keuangan dan Love Of Money pengaruhnya terhadap Pengelolaan Keuangan Pribadi dan dampaknya terhadap Kesejahteraan Masyarakat Desa Cihambulu, Kec. Pabuaran Kab. Subang. Jurnal SEKURITAS (Saham, Ekonomi, Keuangan dan Investasi), 4(1), 43-56.

Rusman. 2012. Model-Model Pembelajaran. Bandung: Mulia Mandiri Press

Siagian, R. E. F. 2012. Pengaruh minat dan kebiasaan belajar siswa terhadap prestasi belajar matematika.Jurnal Formatif, 2(2), 122-131 2012.

Sugiyono. 2011. Metode Penelitian Kuantitatif, Kualitatif dan R\&D. Bandung:Afabeta.

Sumarni.2017. PengaruhKeterampilan Guru Dalam Proses Pembelajaran Terhadap Motivasi Belajar Siswa Kelas X Kompetensi Keahlian Administrasi Perkantoran Di SMK YPLP PGRI Makassar.Skripsi.Fakultas IImu Sosial.Universitas Negeri Makassar.

Sunardi, N., \& Lesmana, R. (2020). Konsep Icepower (Wiramadu) sebagai Solusi Wirausaha menuju Desa Sejahtra Mandiri (DMS) pada Masa Pandemi Covid19. JIMF (Jurnal IImiah Manajemen Forkamma), 4(1).

Sunardi, N., \& Lesmana, R. (2020). Konsep Icepower (Wiramadu) sebagai Solusi Wirausaha menuju Desa Sejahtra Mandiri (DMS) pada Masa Pandemi Covid19. JIMF (Jurnal Ilmiah Manajemen Forkamma), 4(1).

Sunyoto, Danang. (2015). "Manajemen dan Pengembangan Sumber Daya Manusia".Yogyakarta: Center for Academic Publishing Service 